International Journal of Instruction e-ISSN: 1308-1470 • www.e-iji.net

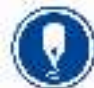

April 2021 • Vol.14, No.2

p-ISSN: 1694-609X

pp. $873-888$

Article submission code:

20200411112120

Received: 11/04/2020

Revision: 30/10/2020

Accepted: 21/11/2020

OnlineFirst: 12/03/2021

\title{
The Effect of Treffinger Creative Learning Model with the Use RME Principles on Creative Thinking Skill and Mathematics Learning Outcome
}

\section{Sabina Ndiung \\ Dr., Universitas Katolik Indonesia Santu Paulus Ruteng, Indonesia, punyaku79@gmail.com}

\section{Sariyasa}

Prof., Universitas Pendidikan Ganesha, Indonesia, sariyasa64@yahoo.com

Emilianus Jehadus

Universitas Katolik Indonesia Santu Paulus Ruteng, Indonesia, rebasarong@gmail.com

Ratih Ayu Apsari

Universitas Mataram, Indonesia, ra.apsari@unram.ac.id

Nowadays, learning should be directed to develop the $21^{\text {st }}$-century core competencies, including creative thinking in problem-solving. Therefore, the present study aimed to improve the students' creative thinking and mathematics learning outcome through the implementation of the Treffinger learning model with Realistic Mathematics Education (RME) principles. To achieve the goals, experiment study with Quasi-Experimental Post-test Only Control Group design had deliberately chosen as the method of the study. The subjects of the present study were 101 fifth graders students in Lelak, Manggarai-Indonesia. The subject was chosen by a random sampling technique. The data related to creative thinking skill and mathematics learning outcomes were collected by using essay tests with five items each. The instruments have been judges as valid by the assessment of five experts and empirically reliable. The hypothesis testing was done by using MANOVA at a 5\% level of the significance level. Hypotheses were tested using MANOVA with the aid of SPSS. The result of the statistical analysis shows that F Wilks' Lambda $=17,195$, and sig. $<0.001$. Since the sig value was less than 0.05 , then it can be argued that simultaneously creative thinking skill and mathematics learning outcome of the students who took mathematics through the Treffinger learning model using RME principles were better than those of their counterparts who learned the same subject through the conventional learning model.

Keywords: creative thinking skill, mathematics learning outcome, Treffinger learning model, RME principles, learning

Citation: Ndiung, S., Sariyasa., Jehadus, E., \& Apsari, R. A. (2021). The Effect of Treffinger Creative Learning Model with the Use RME Principles on Creative Thinking Skill and Mathematics Learning Outcome. International Journal of Instruction, 14(2), 873-888. https://doi.org/10.29333/iji.2021.14249a 


\section{INTRODUCTION}

Education should provide opportunities for students to learn how to be creative in solving problems. It will be beneficial for them as they will be able to survive in the uncertain and competitive conditions in the disruption era (Birgili, 2015). Currently, the goals are to prepare students in mastering 21 st-century skills. Therefore, the learning setting should be adjusted to promote the habits and characters that suitable for the requirement of $4 \mathrm{Cs}$ in 21 st-century skills, which are critical thinking, communication, collaboration, and creativity (Menggo, Suastra, Budiarsa, \& Padmadewi, 2019; Partnership for 21st Century Learning, 2015).

Creativity is a powerful weapon to face various types of problem as it opens the eyes of students to seek on a grounded understanding (Runisah, Herman, \& Dahlan, 2016). It boosts students' cognitive aspect as well as their awareness to assess and evaluate information critically (Changwong, Sukkamart, \& Sisan, 2018). Furthermore, it is considered as High Order Thinking (HOT) skills, which consist of some components such as fluency, flexibility, and originality (Astutik, Mahardika, Indrawati, Sudarti, \& Supeno, 2020; Sriwongchai, 2015; Yusof \& Seman, 2018). In general, fluency refers to the ease in generating several concepts in the creative process; flexibility relates to the capacity to abandon the old way of thinking and embrace new concepts or a new path, and originality involves to produce unpredictable, unusual or unique ideas (Handayani, Hajidin, Duskri, \& Maidiyah, 2018).

A creative student is an effective problem solver. Indeed, mathematics classrooms aimed to develop various skills to enable students to solve their application in daily life (Kızıltoprak \& Köse, 2017). Accordingly, as creativity enhance, the students' performance in mathematics will be increased. The measurement of how mathematics skills are attained by the students in the formal classroom is called the learning outcome. It has three domains of cognitive, affective, and psychomotor. The cognitive area usually is evaluated according to Bloom's Taxonomy revised version, which is the students' ability to remember, understand, apply, analyze, evaluate, and create specific knowledge (Anderson \& Krathwohl, 2001). The assessment of students' learning outcomes provides an insight for the teachers to make a variety of decisions for the upcoming instructional series (Aho, Haverinen, Juuso, Laukka, \& Sutinen, 2010).

A factor that helps in the formation of the students' creative thinking skills and mathematics learning outcome is the teaching model employed by the teacher (Zubaidah, Fuad, Mahanal, \& Suarsini, 2017). In empowering students to be creative, the learning environment should be productive, engage in open-ended investigation and exploration, and accommodate students' cultural values (Palinussa, 2013). It was also found that an exhausting drill leads to the students' difficulty in learning mathematics (Wijaya, Retnawati, Setyaningrum, \& Aoyama, 2019). To overcome the problem, teachers play the role of facilitators in class discussions and encourage them to participate by communicating and developing their ideas. Research showed how useful guidance from the teacher, for instance, by using scaffolding, supports the students' exploration in a student-centered learning setting (Gita \& Apsari, 2018). 
However, the current condition of teaching and learning in Indonesia does not provide enough opportunities for developing the students' creativity and performance in learning. It can be seen from the poor results in the PISA literacy test, where Indonesian students ranked 74th from 79 nations (Ndiung \& Jediut, 2020; OECD, 2019). A similar result also found in TIMSS, where Indonesian students ranked 48th from 50 countries. In general, the students achieved poorly in understanding complex information, applying theory and analysis, using tools, procedures, and problem-solving techniques; and doing investigations (Mullis, Martin, Foy, \& Arora, 2013). Furthermore, it was revealed that students tend to make errors in their mathematical problem-solving process. The research indicated that students made mistakes in contradicting (7.3\%), disregarding evidence (5.2\%), misreading (45.7\%), and opinion-based judgment (40.9\%) (Utomo, Narulita, Yuana, Fikri, \& Wahono, 2018). Reflect on the results of PISA and TIMSS; it is clear that the curriculum should be transformed to enable students to think and act creatively and productively, critically, autonomously, collaboratively, and communicatively. The efforts to develop those abilities should be started as early as possible, including in elementary school levels (Ndiung, Dantes, Ardana, \& Marhaeni, 2019; Setianingsih, Sa'dijah, As'ari, \& Muksar, 2017).

On the other hand, the fact showed how teachers in elementary schools in the Lelak sub-district tend not to be ready to implement a classroom, which will enhance the students' 4 Cs mastery. Based on the preliminary study from an interview and classroom observation with pre-service and in-service elementary school teachers, it was found that there are complex problems that need to be solved before the intended active classroom can be established. First, the teaching paradigm still not moving from teacher domination, which inhibits the students from being creative. Second, the focus of learning more to finish all the materials on the textbook instead of the attainment of learning objectives. Third, the type of problems that emerged in the mathematics classroom less challenging and more emphasizing procedural fluency. Fourth, the classroom assessment and evaluation still not in a holistic form, which makes the students' comprehension cannot be examined comprehensively. These conditions are contrary to the recommendation that the learning process should be enjoyable for the students (Isaksen, Dorval, \& Treffinger, 2011).

Considering the gap between the current situation and the future needs of teaching and learning mathematics in Indonesia, the present study proposes the use of a constructivist model to improve the quality of the mathematics lesson. A constructive mathematics classroom helps students to see mathematics as human activity (Freudenthal, 2002) that they might encounter as a part of their life, both at school and outside. It makes the students quickly understand the content, develop learning skills, creativity, cooperation, critical thinking, and self-confidence (Jia, 2010; Zain, Rasidi, \& Abidin, 2012).

\section{Context and Review of Literature}

Learning occurs most effectively when students can relate what they learned at school to the environment and create meanings from different experiences (Sze Yeng \& Hussain, 2010). Creative thinking occurs when students have to accommodate other 
ways of thinking and accept them. To answer the needs Treffinger learning model provides the solution. It is focus on the students' creative ideas in finding as many as possible ways to solve a problem. When the development of creative ideas to find various solutions can be developed well, then, there is about $60 \%$ guarantee that the next steps will be successful (Darminto, 2013).

Treffinger model emphasis the development of students' creativity through three stages of learning. The stages in the model are basic tools, that cover a number of techniques that are regarded as the basics in creative learning: real problems posing to the students that are suitable with their experiences and levels of knowledge so that they will immediately engage in meaningful learning with more than one answer to a problem. Then, the stage of practice with process, that is, giving the students the chance to apply the skill that they learned at the basic tools stage in a practical situation and the stage of working with problem, in which the students apply the skill they learned at the first two stages in facing the challenges in the real life. At this stage the students use their competence meaningfully in their life (Nisa, 2011).

The use of Treffinger model in teaching has been supported by a number of studies (Dwijanto, Tayani, \& Veronica, 2019; Nizham, Suhendra, \& P., 2017; Pomalato, 2019). Various conclusions from the studies on the use of Treffinger creative learning model showed that it can enhance the students' thinking ability. However, the studies tend to merely mostly focus on the development of creative ability at the higher school levels. To bring the creative setting to the lower grade, it is necessary to combine Treffinger learning model with an approach designed to enable young children doing investigation. In this case, Realistic Mathematics Education (RME) has been recommended by some previous studies (Apsari, Putri, Sariyasa, Abels, \& Prayitno, 2020; Karaca \& Özkaya, 2017; Revina \& Leung, 2018).

RME approach is based in Freudenthal's understanding of mathematics as an activity in find, organize and solve a problem (Gravemeijer, 1999). There are five tenets of RME including phenomenology exploration, the use of vertical instruments, students' construction, interactivity and intertwinement (Treffers, 1987). In addition, there also three design heuristic of RME learning activities, including guided reinvention, didactical phenomenology and the emergent modelling (Gravemeijer \& Bakker, 2006). All of those will be the principles of embedding RME in the Treffinger model focuses on activity, reality, hierarchy, interconnection, interaction, and guidance principles (Heuvel-panhuizen \& Drijvers, 2014).

RME is related to the improvement of activity, motivation, interest, engagement and common sense in learning mathematics for elementary school students. It provides a learning technique through the development of concepts reinventing based on the students' knowledge and helping them solve mathematics problems (Saleh, Charitas, Prahmana, \& Isa, 2018). The use of the RME approach in mathematics learning has been effective in enhancing students' learning outcomes (Zakaria \& Syamaun, 2017), mathematical connection (Makonye, 2014), activities and motivation in mathematics (Arsaythamby \& Zubainur, 2015). It is happened due to the availability of context and 
mathematical models (Apsari, Sariyasa, Putri, Gunawan, \& Prayitno, 2020). It also enhances the students' cooperation and interaction between teacher and students and among the students (Ekowati et al., 2015).

However, they have not dealt with the aspect of creative thinking skill. Hence, this study was oriented to the development of creative skill and mathematics learning outcome at elementary school by integrating Treffinger learning model with RME principles.The Treffinger Creative Learning Model with the RME Principles in this analysis is a teaching that is intentionally developed by integrating the Treffinger Creative Learning Model with the RME Principles. The three phases of the Treffinger Creative Learning Model and the six RME principles will work together to create the following convergence: the basic tools stage uses the theory of reality and the activity that will direct students to the growth of creative thinking skills in the field of fluency. The stage of practice and process uses the theory of interaction and the principle of reality, which guides students to the development of creative thinking skills in the aspect of originality. When dealing with problems is based on the principle of guidance, the principle of hierarchy, the principle of interconnection, which is believed to be aimed towards the growth of creative thinking skills in the area of flexibility. Since mathematics is an abstract science, it will be easily understood by students when it is related to realistic problems that they can imagine. Hence, the RME principles can be integrated well with Treffinger creative learning model in which the teaching is oriented toward the use of a realistic approach in solving mathematics problems creatively.

All in all, considering aforementioned facts, problems and needs, Treffinger learning model combined with the principles of RME are relevant to enhance students' creativity through collaborative setting and positive interaction with the process. Based on the explanation above, this study aimed to examine the effect of Treffinger teaching model with RME principles toward the elementary school students' creative thinking skills and mathematics learning outcome.

\section{METHOD}

\section{Design}

This study was a quasi-experiment with posttest-only design (Creswell, 2012: 314). The aim of the study was to investigate the difference between the experimental group and the control group in creative thinking skills and mathematics learning outcomes. The experiment group was presented with the Treffinger Creative Learning Model based on RME principles, whereas the control group was presented with the conventional Learning Model. The research consisted of three steps, i.e. pre-experiment, experiment, and post-experiment. Treatment was conducted in eight meetings, both for the experimental group and the control group, which was then completed with a post-test to evaluate creative thinking skills and student mathematics learning outcomes.

This study's conventional teaching model refers to the method used by elementary school teachers in the Lelak sub-district in teaching mathematics and discussing topics, which take the form of transfer of knowledge from teacher to student. It usually starts 
with a brief teacher explanation about the topic and continues with the students trying to answer some problems in the book and ends with the presentation of the answers. The characteristic of the conventional teaching model is the tendency for lecturing to dominate, transfer of knowledge from teacher to the student, learning activities tend to be monotonous, one-way communication, a lot of practice in solving problems, without using concrete media, and teacher-centered teaching.

\section{Sample}

The population consisted of 383 fifth graders in 11 elementary schools in the Lelak subdistrict, Manggarai regency. The sampling was done with a random sampling technique (Creswell, 2012: 155). Random sampling according to Dantes (2012: 44) done in several stages, namely (1) Determine the locus of research by selecting schools that have similar characteristics, means the similarity of the educational background of teachers who teach at each school, schools are relatively homogeneous, in the sense of the similarity of the school environment as well as facilities and infrastructure. Eleven elementary schools in the Lelak sub-district have homogenous characteristics with a group of 16 classes; (2) Before a random selection, equality testing is done between classes. Equality testing among classes is used one-way ANOVA test. Class equality is seen from the equality of mathematics learning outcomes obtained from each class's report card grades during the fourth grade class of even semester of the academic year 2017/2018. From 16 classes, based on the result of the equality test, it was found that all 16 classes are equal to each other; (3) From 11 schools, randomly used as a research sample, namely schools and classes based on the first stage above; and (4) obtained two schools as research samples, namely students of the fifth grade of two schools, SDN Watu Weri totaling 52 and SDN Weri Pateng totaling 49 students. The distribution of the number of each sample group member is seen in the Table 1.

Table 1

Distribution of research sample members

\begin{tabular}{llllll}
\hline \multirow{2}{*}{ No } & \multirow{2}{*}{ School } & \multicolumn{2}{l}{ Experimental group } & \multicolumn{2}{l}{ Control group } \\
\cline { 3 - 6 } & & Class & Number of students & Class & Number of students \\
\hline 1 & SDI Watu Weri & VB & 26 & VA & 26 \\
\hline 2 & SDI Weri Pateng & VA & 25 & VB & 24 \\
\hline Total & 2 & 51 & 2 & 50 \\
\hline
\end{tabular}

The experiment group used the Treffinger learning model using RME principles and the control group the conventional learning model. The sample was given treatment in eight meetings, ended with the administration of a creative thinking test and a mathematics learning outcome test. The independent variable was the Treffinger learning model with RME principles, while the dependent variables were the creative skill and mathematics learning outcome of the students.

\section{Data Collection and Analysis}

The data were analyzed by using descriptive and inferential statistical analysis. The data on creative thinking skill and mathematics learning outcomes of the students were 
collected with essay tests; each consisted of 5 items. The rubric of creative thinking skills was adapted from Bosch (La Moma, 2015) using 0-4 scales. The content of the test instrument for measuring mathematics learning outcomes was validated by five experts with doctoral qualifications from the Postgraduate Study of Universitas Pendidikan Ganesha, Bali, examined by content validity ratio (CVR) developed by Lawshe (Newman, Lim, \& Pineda, 2011). The instrument used has been validated and its reliability has been empirically verified. Reliability coefficient of the rubric of the thinking skill was computed based on the reliability among raters. The reliability coefficient was 0.79 falling into a high category, and the reliability coefficient of the learning outcome was 0.79 and was tested using Alpha Cronbach formula. The data were analyzed using Multivariate Analysis of Variance (MANOVA), preceded by an assumption test, i.e., data distribution normality test, homogeneity test of data group variances, and multicollinearity test. Data analysis using the Statistical Package for Social Sciences (SPSS) program for window version 23.0.

\section{FINDINGS}

The hypothesis tested in this study was that the creative thinking skill and mathematics learning outcomes of the students who learned through Treffinger with RME principles are better than those of the students who learned through the conventional learning model. After being given treatment in eight meetings, the creative thinking skills the posttest, and mathematics learning outcomes, the posttest was given. The result of the descriptive statistical analysis of the creative thinking posttest and mathematics learning outcome posttest results of the students can be presented in Table 2 .

Table 2

Recap of descriptive statistical analysis

\begin{tabular}{lllllll}
\hline Variable & Group & $\mathrm{N}$ & Mean & Median & Standard Deviation & Var. \\
\hline Creative & Experiment & 51 & 67.84 & 70 & 10.87 & 118.25 \\
\cline { 2 - 7 } Thinking Skill & Control & 50 & 58.8 & 60 & 9.98 & 99.55 \\
\hline Mathematics & Experiment & 51 & 57,94 & 57 & 8,89 & 79,17 \\
\cline { 2 - 7 } Outcome & Control & 50 & 51,2 & 51 & 7,42 & 55,13 \\
\hline
\end{tabular}

Based on the data in Table 2 above, it can be concluded that the mean of creative thinking skill and the mean of mathematics learning outcome of the students who learned mathematics through the Treffinger learning model with RME principles were higher than those who learned mathematics through the conventional teaching model. Then the assumption tests, in this case, the data distribution normality test, data group variance homogeneity test, and multicolinear test were done. The results of the assumption tests with the aid of the SPSS 23.0 program are shown in Table 3 as follows. 
Table 3

Recap of the results of data normality test

\begin{tabular}{lllcl}
\hline Group & $\mathrm{N}$ & Sig Kolmogorov Smirnov & $\alpha$ & Conclusion \\
\hline $\mathrm{A}_{1} \mathrm{Y}_{1}$ & 51 & 0,151 & 0,05 & Normal Distribution \\
$\mathrm{A}_{2} \mathrm{Y}_{1}$ & 50 & 0,080 & 0,05 & Normal Distribution \\
$\mathrm{A}_{1} \mathrm{Y}_{2}$ & 51 & 0,200 & 0,05 & Normal Distribution \\
$\mathrm{A}_{1} \mathrm{Y}_{2}$ & 50 & 0,095 & 0,05 & Normal Distribution \\
\hline
\end{tabular}

Note:

$A_{1} Y_{1}$ : Data of creative thinking skills with RME Principles Experiment Group

$A_{2} Y_{1}$ : Data of creative thinking skills with RME Principles Control Group

$\mathrm{A}_{1} \mathrm{Y}_{2}$ : Data of mathematics outcome with RME Principles Experiment Group

$\mathrm{A}_{2} \mathrm{Y}_{2}$ : Data of mathematics outcome with RME Principles Control Group

By referring to Table 3 above, it has been shown that all groups of data whose normality was tested have the sig. A Kolmogorov value exceeding 0.05. Therefore, it can be claimed that all groups of creative thinking skill scores and mathematics learning outcome scores of the students in this study come from a population with a normal distribution. Then, the test of variance homogeneity of data on creative thinking skill and data on mathematics learning outcome of the students was done by using Box's test of equality of covariance matrics for testing the homogeneity of variance simultaneously, that is, the group of creative thinking skill and a group of mathematics learning outcome of the students. The result of the analysis of group variance homogeneity with Box's M test can be explained in Table 4.

Table 4

Result of the testing of variance homogeneity

\begin{tabular}{ll}
\hline \multicolumn{2}{l}{ Box's Test of Equality of Covariance Matrics } \\
\hline Box's M & 6.880 \\
\hline F & 2.243 \\
\hline df1 & 3 \\
\hline df2 & 1787036.167 \\
\hline
\end{tabular}

It was referring to the result of the analysis in Table 4 above, the sig. The value of every data group exceeds 0.05 . Therefore, it can be argued that the data group of creative thinking scores and the data group of mathematics learning outcome scores had homogeneous variances. Then, a multicolinear test was done to see the relation between the variables of creative thinking skill and mathematics learning outcome of the students, both of them were dependent variables, and to ascertain that both could be used as different criteria to avoid overlapping. The testing of multicollinearity was done based on the value of the Variance Inflation Factor (VIF) and tolerance value. The result of the analysis of the testing of multicollinearity can be seen in Table 5 below. 
Table 5

Result of multicollinearity test

\begin{tabular}{|c|c|c|c|c|c|c|c|}
\hline \multicolumn{8}{|l|}{ Coefficients } \\
\hline \multirow[t]{2}{*}{ Model } & \multicolumn{2}{|c|}{$\begin{array}{l}\text { Coefficient Non- } \\
\text { standard }\end{array}$} & \multirow{2}{*}{$\begin{array}{l}\text { Coefficient } \\
\text { Standard } \\
\text { Beta } \\
\end{array}$} & \multirow[t]{2}{*}{$\mathrm{T}$} & \multirow[t]{2}{*}{ Sig. } & \multicolumn{2}{|c|}{ Collinearity Statistics } \\
\hline & $\mathrm{B}$ & Std. Error & & & & Tolerance & VIF \\
\hline 1 (Constant) & 35.334 & 3.949 & & 8.948 & .000 & & \\
\hline $\begin{array}{l}\text { Creative Thinking } \\
\text { Skills }\end{array}$ & .220 & .073 & .269 & 3.012 & .003 & .636 & 1.573 \\
\hline $\begin{array}{l}\text { Learning } \\
\text { Mathematics } \\
\text { Outcome }\end{array}$ & .293 & .051 & .513 & 5.739 & .000 & .636 & 1.573 \\
\hline
\end{tabular}

Based on the data from the result of the Multicollinearity test in Table 5 above, a VIF value of less than ten and a tolerance value of more than 0.1 was obtained. Hence, it can be said that the creative thinking skill and mathematics learning outcome variables did not undergo multicollinearity, thus they could be used as different criteria variables. In this case, both variables could be used as criteria variables separately and simultaneously.

Since the result showed that there was no multicollinearity, the procedure was continued to the testing of the hypothesis using Multivariate Analysis of Variance (MANOVA). The hypothesis testing was done by using inferential analysis aided by the SPSS application program version 23.0. The recap of the result of the MANOVA analysis of the data on creative thinking skill and mathematics learning outcome of the students can be seen in Table 6 .

Table 6

Recap of the result of MANOVA of the data on creative thinking skill and mathematics learning outcome

\begin{tabular}{lllllll}
\hline \multicolumn{2}{l}{ Multivariate Tests } \\
\hline Effect & Value & F & $\begin{array}{l}\text { Inter Group } \\
\text { df }\end{array}$ & $\begin{array}{l}\text { Within } \\
\text { Group df }\end{array}$ & Sig. \\
\hline \multirow{3}{*}{ Intercept } & Pillai's Trace & .991 & $5682.327^{\mathrm{a}}$ & 2.000 & 98.000 & $<0.001$ \\
\cline { 2 - 7 } & Wilks' Lambda & .009 & $5682.327^{\mathrm{a}}$ & 2.000 & 98.000 & $<0.001$ \\
\cline { 2 - 7 } & Hotelling's Trace & 115.966 & $5682.327^{\mathrm{a}}$ & 2.000 & 98.000 & $<0.001$ \\
\cline { 2 - 7 } & Roy's Largest Root & 115.966 & $5682.327^{\mathrm{a}}$ & 2.000 & 98.000 & $<0.001$ \\
\hline \multirow{2}{*}{ Learning } & Pillai's Trace & .260 & $17.195^{\mathrm{a}}$ & 2.000 & 98.000 & $<0.001$ \\
\cline { 2 - 7 } & Wilks' Lambda & .740 & $17.195^{\mathrm{a}}$ & 2.000 & 98.000 & $<0.001$ \\
\cline { 2 - 7 } & Hotelling's Trace & .351 & $17.195^{\mathrm{a}}$ & 2.000 & 98.000 & $<0.001$ \\
\cline { 2 - 7 } & Roy's Largest Root & .351 & $17.195^{\mathrm{a}}$ & 2.000 & 98.000 & $<0.001$ \\
\hline
\end{tabular}

Each $\mathrm{F}$ tests the multivariate effect of Learning Model. These tests are based on the linearly independent pairwise comparisons among the estimated marginal means.

a Exact Statistic

b Design: Intercept + Learning Model

By referring to Table 6 above, it was obtained that F Wilks' Lambda $=17,195$, and sig. $<0.001$. Since the sig. The value was less than 0.05 , and then it can be said that 
simultaneously creative thinking skill and mathematics learning outcomes of the students who learned mathematics through the Treffinger teaching model with RME principles were better than those of the students who learned mathematics through the conventional teaching model. The Treffinger learning model with RME principles has also had a strong and important impact on creative thinking skills and mathematics learning outcomes of the students.

\section{DISCUSSION}

Research findings show that creative thinking skills and mathematics learning outcomes of the experimental class students are better than the control class. This indicated by descriptive statistics and hypothesizing testing data. This positive and significant result were influenced by the result of the integration of the three stages of Treffinger learning model with six RME principles. The integration is flexible, in which the six RME principles could be integrated into the stages of Treffinger learning model. At the stage of basic tools, the RME principles involved were the principle of reality, that is realized by posing realistic problems in which the students were faced with examples of problems. Students could imagine and solve the problems by using the principle of activity, in which the students were individually involved in producing many ideas in solving the problems. As an example, determine two fractions of the same type the product of their addition is $\frac{5}{6}$. In answering the problem, the students give a variety of answers according to their knowledge.

At this stage, most of the students were able to solve well-problems, in which they were able to give more than one idea relevant to the problem. The making of the students accustomed of the activity in this stage was able to lead the creative thinking skill process of the students to the fluency aspect. The finding of this study is relevant to Treffinger view, who states that the most strategic step in solving problems is the basic steps. There, students' the basics of the development of functions and creative basic ability, both cognitive and affective, can be assessed. When the effort to find various solutions can be developed successfully, then there will be about $60 \%$ guarantee that other steps will succeed. The basic tools stage can also lead the students to solve nonroutine problems and this has an impact on the improvement in their mathematics learning outcome. This agrees with the previous finding that Treffinger learning model can have a positive contribution to the development of students' creative thinking skills and ability to solve mathematical problems (Ridwan, Ridwan, Supriyadi, \& Nurmanita, 2019).

The stage of practice with process, three principles of RME involved, such as interaction principle, which highlights on group discussion activity; reality principle, which reflects the realistic problems discussed in the group; and the principle of activity, that is, stimulate the students to communicating their ideas and responding to each other based on the ideas being expressed. The students are grouped based on their abilities, and each group consists of 4-5 members. This concept aligns with Vygotsky's ZPD concept. 
Zone of Proximal Development (ZPD) is the zone in which the student cannot solve difficult tasks alone but needs a guidance or assistance from adult or other students who have more capabilities (Denhere, Kudzai, \& Josiah, 2013). Throughout this case, ZPD is a distance between the level of real development demonstrated by the ability to solve problems independently and the level of potential developmental capacity proven by the ability to solve problems with the aid of adults or by collaborating together with peers who are more capable (Siyepu, 2013). Based on the problem given, most of them were able to give answers with uncommon ideas with correct operational process and result. Familiarization with the learning activities at this stage can guide the creative thinking skill process to the originality aspect, i.e., the students can give ideas or ways of thinking that are different from other ways. Besides, Treffinger model with RME principles could stimulate students in solving mathematical problems up to non-routine problem solving that requires students to have high order thinking skills, and their mathematics learning outcome increased as well (Ndiung, 2020a).

The stage of working with real problems, the RME principle used was the principle of guidance, in this case through the teacher's guidance, the students could construct problems and their solutions autonomously, and the group also used the principle of networking by connecting their previous knowledge especially to solve the fraction problem and the principle of gradation, that is, the students can solve realistic problems gradually through the process of problem solving informally toward formal problem solving. This can be seen in the result of analysis of the process of solving the problems given to the students in which they were able to give answers in more than one way with correct computational processes and results. The steps in solving problems taken at the stage of working with real problems are in line with Jerome Bruner's learning theory that states that for the teaching to be able to develop the students' intellectual ability in learning some knowledge (e.g., mathematical concepts), the teaching materials need to be presented by considering the stage of cognitive/knowledge development of the students in order the materials can be internalized in their cognitive structure (Ardana, Wisna Ariawan, \& Hendra Divayana, 2017). According to Bruner, the internalization process will really occur (which means that the learning process occurs optimally) if the knowledge that is taught is learned in three stages of models, namely the enactive model, iconic model, and symbolic model. Bruner's opinion supports Jean Piaget's theory that states that human thinking process follows the gradual development from intellectual thinking to abstract thinking (Richland, Frausel, \& Begolli, 2016). In this case, the students at the elementary school ages (7-12) are at the concrete operational phase. Thus, knowledge is presented from concrete stage to abstract stage.

This is different from the situation of teaching that uses the conventional learning model. The learning that uses the conventional learning model tends to be oriented to the less challenging thinking process since the students are not given enough opportunities to solve problems by themselves since they tend to be teacher-directed. The problems presented are dominantly those that do not need advanced thinking knowledge so that the students are less creative. Hence, it can be said that simultaneously, the creative thinking skill of the students who learn mathematics 
through Treffinger learning model is better than those who learn mathematics through the conventional learning model.

This is different from the situation of teaching that uses the conventional learning model. The learning that uses the conventional learning model tends to be oriented to the less challenging thinking process since the students are not given enough opportunities to solve problems by themselves since they tend to be teacher-directed. The problems presented are dominantly those that do not need advanced thinking knowledge so that the students are less creative. Hence, it can be said that simultaneously, the creative thinking skill of the students who learn mathematics through the Treffinger learning model is better than those who learn mathematics through the conventional learning model.

\section{CONCLUSION}

The Treffinger learning model is one of the learning models with a creative technique that can guide students to be able to solve problems unusually by involving realistic problems originating from students' real life. The result of this study shows that the creative thinking skill and mathematics learning outcome of the students who learn mathematics through the Treffinger learning model with realistic mathematics education approaches are better than those of their counterparts who learn mathematics through the conventional teaching model both separately and simultaneously. It can be said that the integration of Treffinger's creative learning model combined with the six principles of RME as one of the learning models that can be used by elementary school teachers in mathematics learning to shape creative thinking skills while enhancing mathematics learning outcomes. The treatment of this research is still limited to fractional material. Therefore, to prove its effectiveness in other materials or for other subjects can be done in further research and/or by subsequent researchers.

\section{REFERENCES}

Aho, E., Haverinen, H. L., Juuso, H., Laukka, S. J., \& Sutinen, A. (2010). Teacher's principles of decision-making and classroom management; A case study and a new observation method. Procedia - Social and Behavioral Sciences, 9, 395-402. https://doi.org/10.1016/j.sbspro.2010.12.171

Anderson, L. W., \& Krathwohl, D. R. (2001). A Taxonomy for Learning, Teaching, and Assessing: A Revision of Bloom's Taxonomy of Educational Objectives. New York: Addison Wesley Longman, Inc.

Apsari, R. A., Putri, R. I. I., Sariyasa, Abels, M., \& Prayitno, S. (2020). Geometry representation to develop algebraic thinking: A recommendation for a pattern investigation in pre-algebra class. Journal on Mathematics Education, 11(1), 45-58. https://doi.org/10.22342/jme.11.1.9535.45-58

Apsari, R. A., Sariyasa, S., Putri, R. I. I., Gunawan, G., \& Prayitno, S. (2020). Understanding Students ' Transition from Arithmetic to Algebraic Thinking in the PreAlgebraic Lesson Understanding Students' Transition from Arithmetic to Algebraic 
Thinking in the Pre-Algebraic Lesson. Journal of Physics: Conference Series, 1471, 17. https://doi.org/10.1088/1742-6596/1471/1/012056

Ardana, I. M., Wisna Ariawan, I. P., \& Hendra Divayana, D. G. (2017). Measuring the Effectiveness of BLCS Model (Bruner, Local Culture, Scaffolding) in Mathematics Teaching by using Expert System-Based CSE-UCLA. International Journal of Education and Management Engineering, 7(4), 1-12. https://doi.org/10.5815/ijeme.2017.04.01

Arsaythamby, V., \& Zubainur, C. M. (2015). How a Realistic Mathematics Educational Approach Affect Students' Activities in Primary Schools? Procedia - Social and Behavioral Sciences, 159, 309-313. https://doi.org/10.1016/j.sbspro.2014.12.378

Astutik, S., Mahardika, I. K., Indrawati, Sudarti, \& Supeno. (2020). HOTS student worksheet to identification of scientific creativity skill, critical thinking skill and creative thinking skill in physics learning. Journal of Physics: Conference Series, 1465(1). https://doi.org/10.1088/1742-6596/1465/1/012075

Birgili, B. (2015). Creative and Critical Thinking Skills in Problem-based Learning Environments. Journal of Gifted Education and Creativity, 2(2), 71-71. https://doi.org/10.18200/jgedc.2015214253

Changwong, K., Sukkamart, A., \& Sisan, B. (2018). Critical thinking skill development: Analysis of a new learning management model for Thai high schools. Journal of International Studies, 11(2), 37-48. https://doi.org/10.14254/2071-8330.2018/11-2/3

Darminto, B. P. (2013). Improving the ability of students' mathematical problem solving. Jurnal Pendidikan Matematika Dan Sains, 1(2), 101-107.

Denhere, C., Kudzai, C., \& Josiah, M. (2013). Vygotsky's Zone of Proximal Development Theory: What are its Implications for Mathematical Teaching? Greener Journal of Social Sciences, 3(7), 371-377. https://doi.org/10.15580/gjss.2013.7.052213632

Dwijanto, Tayani, M., \& Veronica, R. B. (2019). The mathematical creative thinking ability viewed from learning interest in eleventh grade of vocational high school by using treffinger model assisted by problem card. Unnes Journal of Mathematics Education, 8(1), 26-33. https://doi.org/10.15294/ujme.v8i1.29349

Ekowati, C. K., Ardi, M., Darwis, M., Pua, H. M. D., Tahmir, S., \& Dirawan, G. D. (2015). The Application of Realistic Mathematics Education Approach In Teaching Mathematics In Penfui Kupang. International Journal of Education and Information Studies, 5(1), 35-43.

Freudenthal, H. (2002). Revisiting Mathematics Education. In Revisiting Mathematics Education. https://doi.org/10.1007/0-306-47202-3

Gita, I. N., \& Apsari, R. A. (2018). Scaffolding in problem based learning to increase students' achievements in linear algebra. Journal of Physics: Conference Series, 
1040(1). https://doi.org/10.1088/1742-6596/1040/1/012024

Gravemeijer, K. (1999). 1999GravemeijerHowEmergentModelsMathematicalThinking. Mathematical Thinking and Learning, 1(2), 155-177.

Gravemeijer, K., \& Bakker, A. (2006). Design research and design heuristics in statistics education. In Voorburg (Ed.), Proceedings of the Seventh International Conference on Teaching Statistics (pp. 1-6). International Statistical Institute.

Handayani, R., Hajidin, Duskri, M., \& Maidiyah, E. (2018). Development of learning tools using Treffinger learning model to improve creative thinking. Journal of Physics: Conference Series, 1088. https://doi.org/10.1088/1742-6596/1088/1/012090

Heuvel-panhuizen, M. Van Den, \& Drijvers, P. (2014). Realistic Mathematics Education. Encyclopedia OfMathematics Education,. https://doi.org/10.1007/978-94007-4978-8

Isaksen, S. G., Dorval, K. B., \& Treffinger, D. J. (2011). Creative approaches to problem solving: a framework for change. Thousand Oaks, CA: Sage Publications.

Jia, Q. (2010). A Brief Study on the Implication of Constructivism Teaching Theory on Classroom Teaching Reform in Basic Education. International Education Studies, 3(2), 197-199. https://doi.org/10.5539/ies.v3n2p197

Karaca, S. Y., \& Özkaya, A. (2017). The Effects of Realistic Mathematics Education on Students' Math Self Reports in Fifth Grades Mathematics Course conditions of the Creative Commons Attribution license (CC BY-NC-ND). International Journal of Curriculum and Instruction, 9(1), 81-103.

Kizıltoprak, A., \& Köse, N. Y. (2017). Relational thinking: The bridge between arithmetic and algebra. International Electronic Journal of Elementary Education, Vol. 10, pp. 131-145. https://doi.org/10.26822/iejee.2017131893

Menggo, S., Suastra, I. M., Budiarsa, M., \& Padmadewi, N. N. (2019). Needs analysis of academic-English speaking material in promoting 21 st century skills. International Journal of Instruction, 12(2), 739-754. https://doi.org/10.29333/iji.2019.12247a

Mullis, I. V. S., Martin, M. O., Foy, P., \& Arora, A. (2013). TIMSS 2015 International Result in Mathematics. In New Direction for Youth Development. https://doi.org/https://doi.org/10.1002/yd.20038

Ndiung, S., Dantes, N., Ardana, I. M., \& Marhaeni, A. (2019). Treffinger Creative Learning Model with RME Principles on Creative Thinking Skill by Considering Numerical Ability. International Journal of Instruction, 12(3), 731-744. https://doi.org/doi:10.29333/iji.2019.12344a

Ndiung, S., \& Jediut, M. (2020). Pengembangan instrumen tes hasil belajar matematika peserta didik sekolah dasar berorientasi pada berpikir tingkat tinggi. Premiere Educandum: Jurnal Pendidikan Dasar Dan Pembelajaran Volume, 10(June), 94-111. https://doi.org/10.25273/pe.v10i1.6274 
Nisa, T. F. (2011). Pembelajaran Matematika dengan Setting Model Treffinger Untuk Mengembangkan Kreativitas Siswa. Pedagogia, 1(1), 35-48.

Nizham, H., Suhendra, S., \& P., B. A. (2017). Improving ability mathematic literacy, self-efficacy and reducing mathematical anxiety with learning Treffinger model at senior high school students. International Journal of Science and Applied Science: Conference Series, 2(1), 130. https://doi.org/10.20961/ijsascs.v2i1.16696

OECD. (2019). PISA 2018: Insight and Interpretations.

Palinussa, A. L. (2013). Students' critical mathematical thinking skills and character: Experiments for junior high school students through realistic mathematics education culture-based. Journal on Mathematics Education, 4(1), 75-94. https://doi.org/10.22342/jme.4.1.566.75-94

Partnership for 21st Century Learning. (2015). P21 Framework Definitions. In Partnership for 21 st Century Learning. Washington: Pearson.

Pomalato, S. W. D. (2019). Integration of Treffinger model to increase students ' creative thinking and mathematics problem solving ability: an experimental study on 8th grade students in Gorontalo. 2, 228-233.

Revina, S., \& Leung, F. K. S. (2018). Educational Borrowing and Mathematics Curriculum: Realistic Mathematics Education in the Dutch and Indonesian Primary Curriculum. International Journal on Emerging Mathematics Education, 2(1), 1. https://doi.org/10.12928/ijeme.v2i1.8025

Richland, L. E., Frausel, R. R., \& Begolli, K. (2016). Cognitive development. In The SAGE Encyclopedia of Theory in Psychology. https://doi.org/https://doi.org/10.4135/9781483346274.n50

Ridwan, R., Ridwan, Supriyadi, E., \& Nurmanita, M. (2019). The Effect of Treffinger Learning Model on Critical Thinking Ability of Students in SMK 3 Yogyakarta. 326(Iccie 2018), 445-451. https://doi.org/10.2991/iccie-18.2019.78

Runisah, Herman, T., \& Dahlan, J. A. (2016). The Enhancement of Students' Creative Thinking Skills in Mathematics through The 5E Learning Cycle with Metacognitive Technique. International Journal of Education and Research, 4(7), 347-360.

Saleh, M., Charitas, R., Prahmana, I., \& Isa, M. (2018). IMPROVING THE REASONING ABILITY OF ELEMENTARY SCHOOL STUDENT THROUGH THE INDONESIAN REALISTIC. Journal on Mathematics Education, 9(1), 41-54.

Setianingsih, R., Sa'dijah, C., As'ari, A. R., \& Muksar, M. (2017). Investigating FifthGrade Students ' Construction of Mathematical Knowledge through Classroom Discussion. International Electronic Journal of Mathematics Education, 12(4), 383396.

Siyepu, S. (2013). The zone of proximal development of mathematics. South African Journal of Education, 33(2), 1-13. 
Sriwongchai, A. (2015). Developing the Mathematics Learning Management Model for Improving Creative Thinking In Thailand. International Education Studies, 8(11), 77. https://doi.org/10.5539/ies.v8n11p77

Sze Yeng, F., \& Hussain, R. M. R. (2010). Self-directed learning in a socioconstructivist learning environment. Procedia - Social and Behavioral Sciences, 9, 1913-1917. https://doi.org/10.1016/j.sbspro.2010.12.423

Treffers, A. (1987). Three dimensions: A model of goal and theory description in mathematics instruction - the Wiskobas project. Dordrecht: D. Reidel Publishing Company.

Utomo, A. P., Narulita, E., Yuana, K., Fikri, K., \& Wahono, B. (2018). Students' errors in solving science reasoning-domain of trends in international mathematics and science study (TIMSS). Jurnal Pendidikan IPA Indonesia, 7(1), 48-53. https://doi.org/10.15294/jpii.v7i1.11352

Wijaya, A., Retnawati, H., Setyaningrum, W., \& Aoyama, K. (2019). Diagnosing Students 'Learning Difficulties in the E Yes. 10(3), 357-364.

Yusof, W., \& Seman, S. (2018). Teachers' Knowledge of Higher Order Thinking and Questioning Skills: A Case Study at a Primary School in Terengganu. Malaysia. International Journal of Academic Research in Progressive Education and Development, 7(2), 45-63. https://doi.org/10.6007/IJARPED/v7-i2/4120

Zain, S. F. H. S., Rasidi, F. E. M., \& Abidin, I. I. Z. (2012). Student-Centred Learning In Mathematics Constructivism In The Classroom. Journal of International Education Research (JIER), 8(4), 319-328. https://doi.org/10.19030/jier.v8i4.7277

Zakaria, E., \& Syamaun, M. (2017). The Effect of Realistic Mathematics Education Approach on Students' Achievement And Attitudes Towards Mathematics. Mathematics Education Trends and Research, 2017(1), 32-40. https://doi.org/10.5899/2017/metr-00093

Zubaidah, S., Fuad, N. M., Mahanal, S., \& Suarsini, E. (2017). Improving creative thinking skills of students through Differentiated Science Inquiry integrated with mind map. Journal of Turkish Science Education, 14(4), 77-91. https://doi.org/10.12973/tused.10214a 